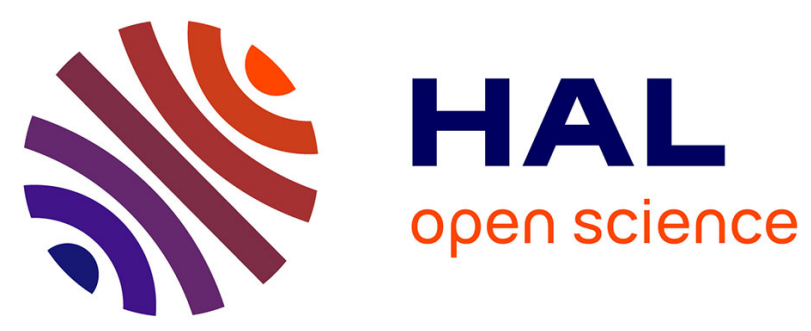

\title{
Mesostictinae subfam. nov., an archaic group of platystictid damselflies (Odonata: Zygoptera) from mid-Cretaceous Burmese amber
}

Daran Zheng, Bo Wang, André Nel, Edmund A Jarzembowski, Haichun Zhang, Su-Chin Chang

\section{To cite this version:}

Daran Zheng, Bo Wang, André Nel, Edmund A Jarzembowski, Haichun Zhang, et al.. Mesostictinae subfam. nov., an archaic group of platystictid damselflies (Odonata: Zygoptera) from mid-Cretaceous Burmese amber. Journal of Systematic Palaeontology, 2019, 17 (1), pp.1-8. 10.1080/14772019.2017.1348395 . hal-02054135

\section{HAL Id: hal-02054135 \\ https: / hal.sorbonne-universite.fr/hal-02054135}

Submitted on 1 Mar 2019

HAL is a multi-disciplinary open access archive for the deposit and dissemination of scientific research documents, whether they are published or not. The documents may come from teaching and research institutions in France or abroad, or from public or private research centers.
L'archive ouverte pluridisciplinaire HAL, est destinée au dépôt et à la diffusion de documents scientifiques de niveau recherche, publiés ou non, émanant des établissements d'enseignement et de recherche français ou étrangers, des laboratoires publics ou privés. 


\title{
Mesostictinae subfam. nov., an archaic group of platystictid damselflies (Odonata: Zygoptera) from mid-Cretaceous Burmese amber
}

\author{
Daran Zheng ${ }^{\mathrm{a}, \mathrm{b} *}$, Bo Wang ${ }^{\mathrm{a}, \mathrm{c}}$, André Nel $^{\mathrm{d}}$, Edmund A. Jarzembowski ${ }^{\mathrm{a}, \mathrm{e}}$, Haichun Zhang ${ }^{\mathrm{a}}$ and Su-Chin Chang ${ }^{\mathrm{b} *}$ \\ ${ }^{a}$ State Key Laboratory of Palaeobiology and Stratigraphy, Nanjing Institute of Geology and Palaeontology, Chinese Academy of \\ Sciences, 39 East Beijing Road, Nanjing 210008, China; ${ }^{b}$ Department of Earth Sciences, The University of Hong Kong, Hong Kong \\ Special Administrative Region, China; ${ }^{c}$ Key Laboratory of Zoological Systematics and Evolution, Institute of Zoology, Chinese Academy \\ of Sciences, 1, Beichen West Road, Beijing 100101, China; ' Institut de Systématique, Évolution, Biodiversité, ISYEB-UMR 7205-CNRS, \\ MNHN, UPMC, EPHE, Muséum national d'Histoire naturelle, Sorbonne Universités, 57 rue Cuvier, CP 50, Entomologie, F-75005, \\ Paris, France; ${ }^{e}$ Department of Earth Sciences, Natural History Museum, London SW7 5BD, UK
}

\begin{abstract}
Odonatans are quite rare in the fossil record compared with the other insects, especially in Cretaceous amber inclusions. The extant family Platystictidae is one of the most diverse Zygoptera, but short of fossil records. In this paper, a new species, Mesosticta davidattenboroughi sp. nov., is described from mid-Cretaceous Burmese amber, representing the thirdknown fossil species of Platystictidae. Mesosticta davidattenboroughi sp. nov. has a long IR1 beginning one cell distal of the base of RP2, confirming the previous attribution of Mesosticta Huang, Azar, Cai \& Nel, 2015 to Platystictidae. It differs from other species of Mesosticta in having a long IR1 and a basally crossed subdiscoidal cell. The fossil genus Mesosticta shares the diagnostic characters of the modern platystictid genera, viz. a basally recessed 'CuP' (shared by all species), a very long IR1 (only in Mesosticta davidattenboroughi sp. nov.), and a specialized subdiscoidal area mostly rhomboidal in shape (only in Mesosticta electronica Zheng, Zhang, Chang \& Wang, 2016). Based on the platystictid damselflies from Burmese amber, a new subfamily Mesostictinae subfam. nov. is established. Mesostictinae subfam. nov. represents the first fossil group of modern platystictid damselflies, documenting the appearance of Platystictidae as early as mid-Cretaceous. It differs from modern Platystictidae by the presence of fewer postnodal and postsubnodal crossveins, a short MP, the base of RP2 being nearer to the subnodus and the nodus lying more distally.
\end{abstract}

http://zoobank.org/urn:lsid:zoobank.org:pub:6669DBCD-F2EF-4C84-9623-BD33142AD36B

Keywords: Platystictidae; Zygoptera; Odonata; Cenomanian; Cretaceous; Burmese amber

\section{Introduction}

Platystictidae (shadowdamsels) currently consist of about 250 extant species in eight genera and four tropical subfamilies (Wilson 1997; Van Tol 2005; Van Tol et al. 2009; Dow \& Orr 2012; Dijkstra et al. 2014; Haber \& Wagner 2014; Schorr \& Paulson 2015; Suhling et al. 2015; Dow et al. 2016; Phan \& Kompier 2016; Bedjanič et al. 2016), and two fossil species of the genus Mesosticta Huang, Azar, Cai \& Nel, 2015 from mid-Cretaceous Burmese amber (Huang et al. 2015; Zheng et al. 2016a). The subfamily Palaemnematinae (Palaemnema Selys, 1860) is confined to central and north-western South America, while Sinostictinae (Sinosticta Wilson, 1997), Platystictinae (Platysticta Selys, 1860, Ceylonosticta Fraser, 1931) and Protostictinae (Protosticta Selys, 1885, Drepanosticta Laidlaw, 1917, Telosticta Dow \& Orr, 2012 and Sulcosticta van Tol, 2005) are restricted to South-East Asia.
Platystictidae were hypothesized to have originated from eastern Africa during the Late Cretaceous, then later migrated to South America, Asia and New Guinea (van Tol \& Müller 2003; van Tol et al. 2009; Sánchez-Herrera $\&$ Ware 2012). The recently discovered Mesosticta, however, puts the appearance of Platystictidae back to at least the mid-Cretaceous (Zheng et al. 2016a).

The platystictid damselflies are characterized by a long and very slender abdomen, and a unique wing with a basally recessed 'CuP' (Fraser 1957; Jarzembowski et al. 1998; Huang et al. 2015), a long IR1 and a usually diamond-shaped subdiscoidal cell (Haber \& Wagner 2014). The platystictid genus Mesosticta (M. burmatica Huang, Azar, Cai \& Nel, 2015 and M. electronica Zheng, Zhang, Chang \& Wang, 2016) was tentatively attributed to this family due to a basally recessed CuP-crossing (Huang et al. 2015) and the rhomboidal shape of the subdiscoidal triangle (only present in the hindwing of M. electronica;

*Corresponding authors. E-mail: dranzheng@gmail.com; suchin@hku.hk 
Zheng et al. 2016a). Both species, however, do not have a very long IR1, which is present in all recent platystictid damselflies. In this paper, we describe a new platystictid species of Mesosticta from mid-Cretaceous Burmese amber. The new species has a very long IR1, so it confirms the previous attribution of Mesosticta to the Platystictidae. Based on three species of Mesosticta, a new subfamily is established.

\section{Geological background}

The piece of amber containing the new damselfly was collected in the Hukawng Valley $\left(26^{\circ} 29^{\prime} \mathrm{N}, 96^{\circ} 35^{\prime} \mathrm{E}\right)$ of Kachin Province, Myanmar (locality in Kania et al. 2015, fig. 1). Abundant insect inclusions have been described from Burmese amber (Cruickshank \& Ko 2003; Shi et al. 2012; Kania et al. 2015), with rare odonatans including true dragonflies (Schädel \& Bechly 2016), damsel-dragonflies (Bechly \& Poinar 2013) and damselflies (Poinar et al. 2010; Huang et al. 2015; Zheng et al. 2016a, b, c, d). The age of the Burmese amber was considered to be Late Albian to Cenomanian based on palynology and ammonite stratigraphy (Cruickshank \& Ko 2003; Ross et al. 2010), while it was radiometrically dated at $98.79 \pm$ $0.62 \mathrm{Ma}$ (earliest Cenomanian) based on U-Pb zircon dating of the volcanoclastic matrix (Shi et al. 2012). The real depositional age of the amber is probably earlier than this radiometric age since the amber shows evidence of redeposition (Wang et al. 2015). Here we follow the age given by Shi et al. (2012), but we treat it as minimal.

\section{Material and methods}

The piece of amber containing the damselfly is yellow and transparent. The damselfly is near the amber surface, and well preserved with complete forewings. The abdomen and hindwings were polished away. Photographs were taken using a Zeiss Stereo Discovery V16 microscope system and Zen software. In most instances, incident and transmitted light were used simultaneously. All images are digitally stacked photomicrographic composites of approximately 40 individual focal planes obtained using the free software Combine ZP for a better illustration of the three-dimensional structures. The line drawings were

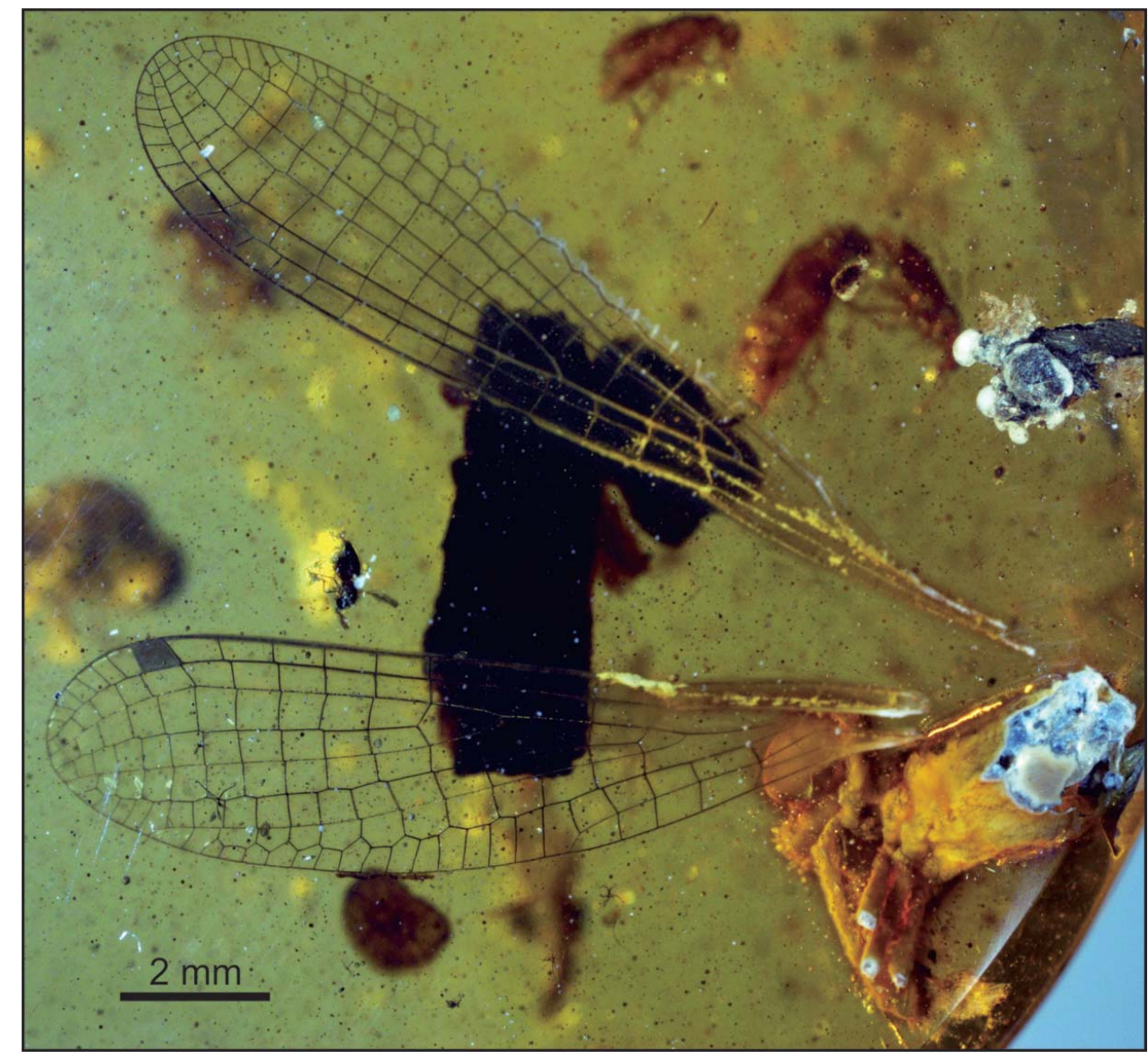

Figure 1. Mesosticta davidattenboroughi sp. nov., holotype, NIGP164541, photograph of specimen. 
prepared from photographs using image-editing software (CorelDraw X7 and Adobe Photoshop CS6). The specimen is housed in the Nanjing Institute of Geology and Palaeontology, Chinese Academy of Sciences (NIGPAS).

The nomenclature of the dragonfly wing venation used in this paper is based on the interpretations of Riek (1976) and Riek \& Kukalová-Peck (1984), as modified by Nel et al. (1993) and Bechly (1996). The phylogeny of extant Zygoptera followed in the present work is based on Dijkstra et al. (2014), while the generic characters of Mesosticta are after Zheng et al. (2016a). Wing abbreviations are as follows: AA, anal anterior; $\mathbf{A P}$, anal posterior; Arc, arculus; Ax, primary antenodal crossvein; $\mathbf{C r}$, nodal crossvein; $\mathbf{C u A}$, cubitus anterior; $\mathbf{C u P}$, cubitus posterior; DC, discoidal cell; IR, intercalary radial vein; MA, median anterior; MP, median posterior; $\mathbf{N}$, nodus; $\mathbf{P t}$, pterostigma; RA, radius anterior; RP, radius posterior; ScP, subcosta posterior; Sn, subnodal crossvein.

\section{Systematic palaeontology}

Order Odonata Fabricius, 1793

Suborder Zygoptera Selys-Longchamps, 1854

Superfamily Platystictoidea Kennedy, 1920

Family Platystictidae Kennedy, 1920

Subfamily Mesostictinae subfam. nov.

Type genus. Mesosticta Huang, Azar, Cai \& Nel, 2015.

Diagnosis. Base of RP3/4 just basal of Sn; base of RP2 three or four cells distal of Sn; MA long and ending on posterior wing margin just below Pt brace; MP three or four cells long; $\mathrm{CuP}$ in basal position; crossvein present basally closing subdiscoidal cell, seperate from $\mathrm{CuP}$; subdiscoidal cell posteriorly closed by AA and not by posterior wing margin; RP1 with slight angle below pterostigmal brace; few postnodal and postsubnodal crossveins (less than 10), somewhat aligned; nodus not in very basal position, at least at $35 \%$ of wing length; longitudinal veins RA, RP1, IR1, RP2 and IR2 strongly converging on wing apex; Pt one cell long, thickened and fused with greatly thickened pterostigmal part of RA as U-shaped structure.

\section{Mesosticta Huang, Azar, Cai \& Nel, 2015}

Type species. Mesosticta burmatica Huang, Azar, Cai \& Nel, 2015.

Included species. Mesosticta electronica Zheng, Zhang, Chang \& Wang, 2016; Mesosticta davidattenboroughi sp. nov.

Revised diagnosis. As for subfamily diagnosis.

\section{Mesosticta davidattenboroughi sp. nov.}

(Figs 1-7)

Type species. NIGP164541, two complete forewings attached to body.

Diagnosis. Forewing characters: IR1 long, originating one cell distal of base of RP2, nearer to $\mathrm{N}$ than to Pt; Arc aligned with Ax2; subdiscoidal cell basally crossed by one vein.

Etymology. In honour of Sir David Attenborough, on his 90th birthday, for his appreciation of dragonflies.

Locality and horizon. Hukawng Valley, Kachin Province, Myanmar; lowermost Cenomanian, lowermost Upper Cretaceous.

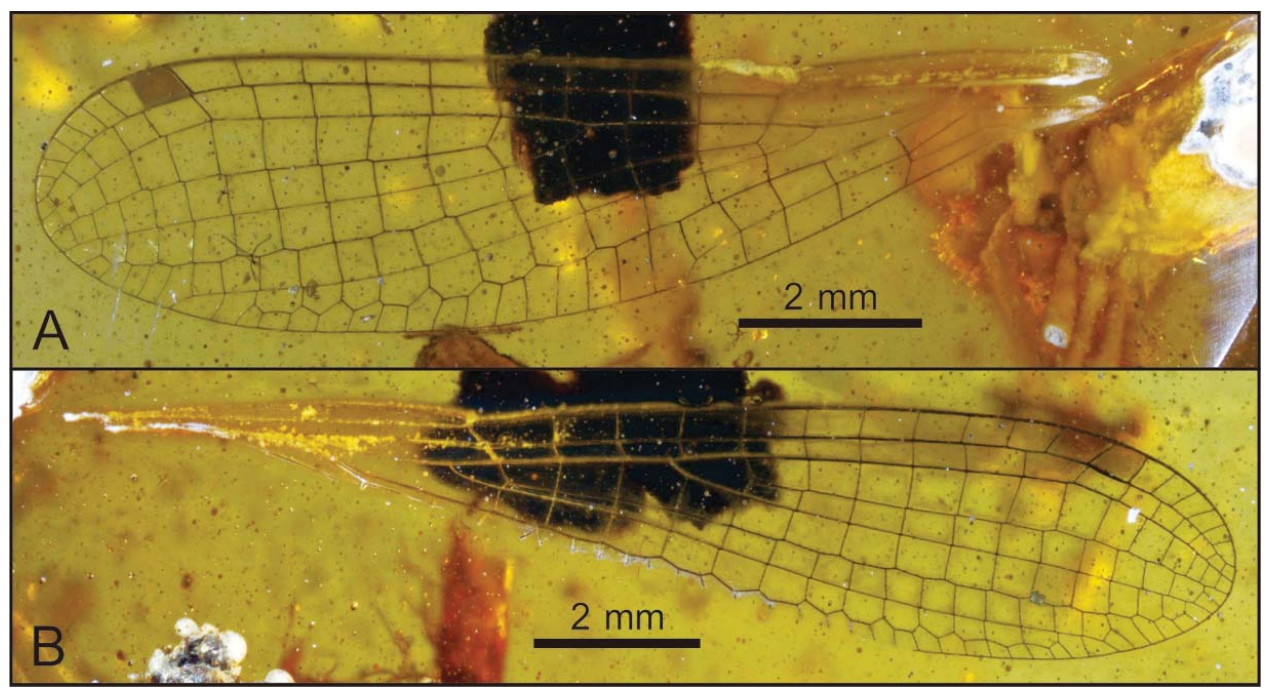

Figure 2. Mesosticta davidattenboroughi sp. nov., holotype, NIGP164541. A, photograph of left forewing; B, photograph of right forewing. 


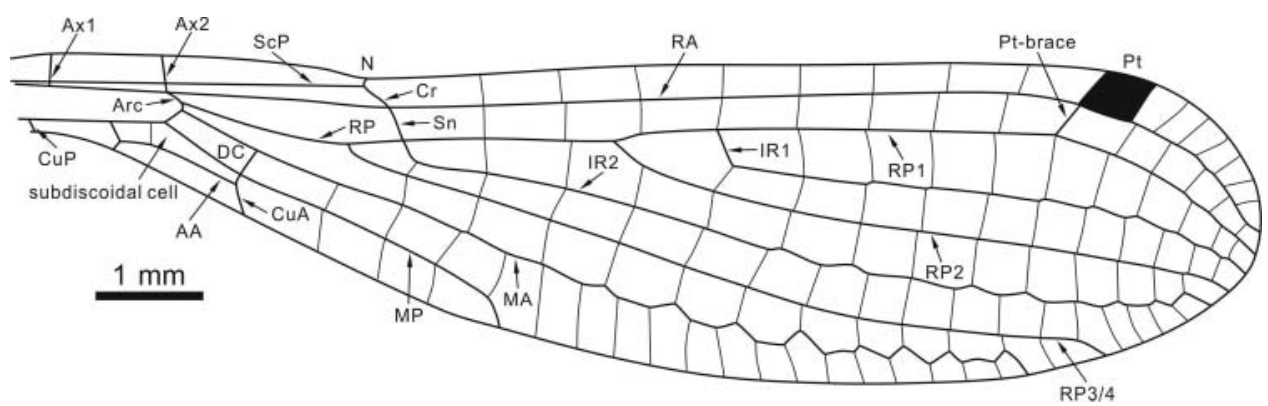

Figure 3. Mesosticta davidattenboroughi sp. nov., holotype, NIGP164541, line drawing showing venation of left forewing.

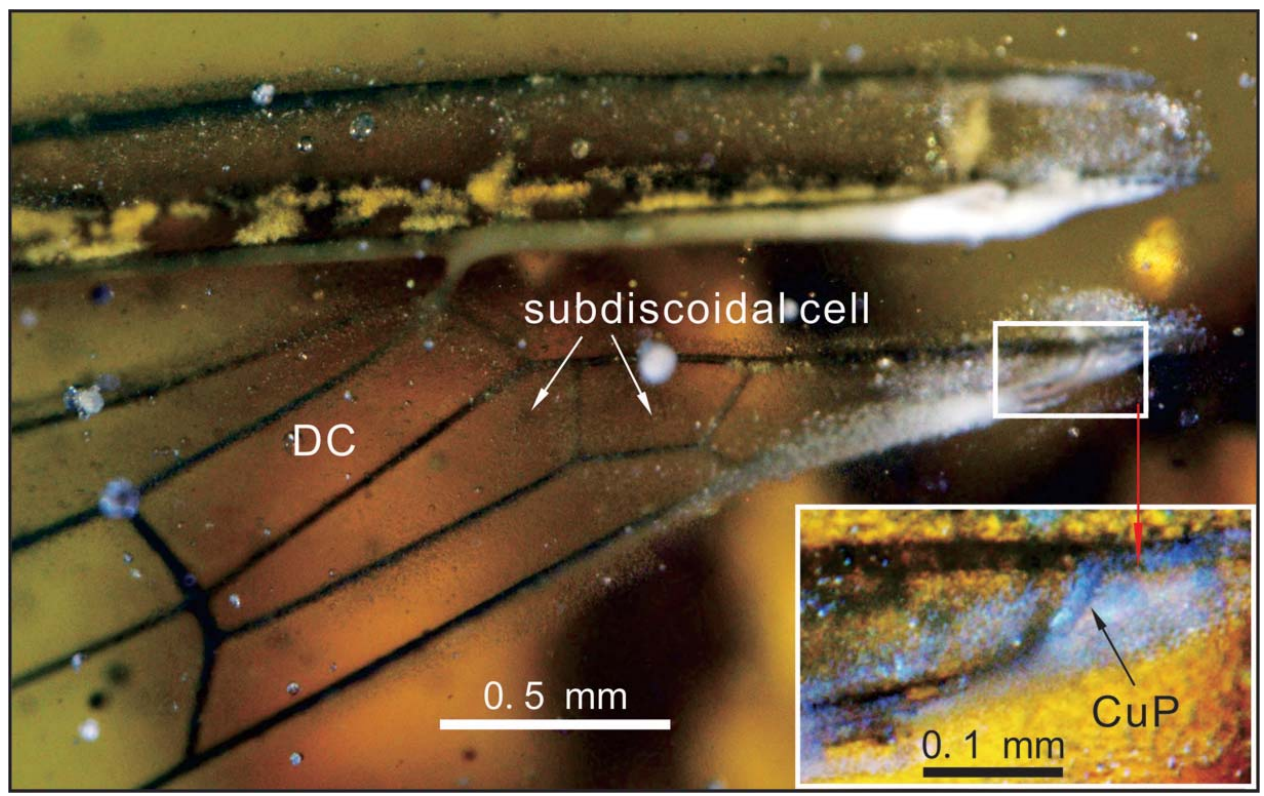

Figure 4. Mesosticta davidattenboroughi sp. nov., holotype, NIGP164541, photograph showing detail of left forewing base.

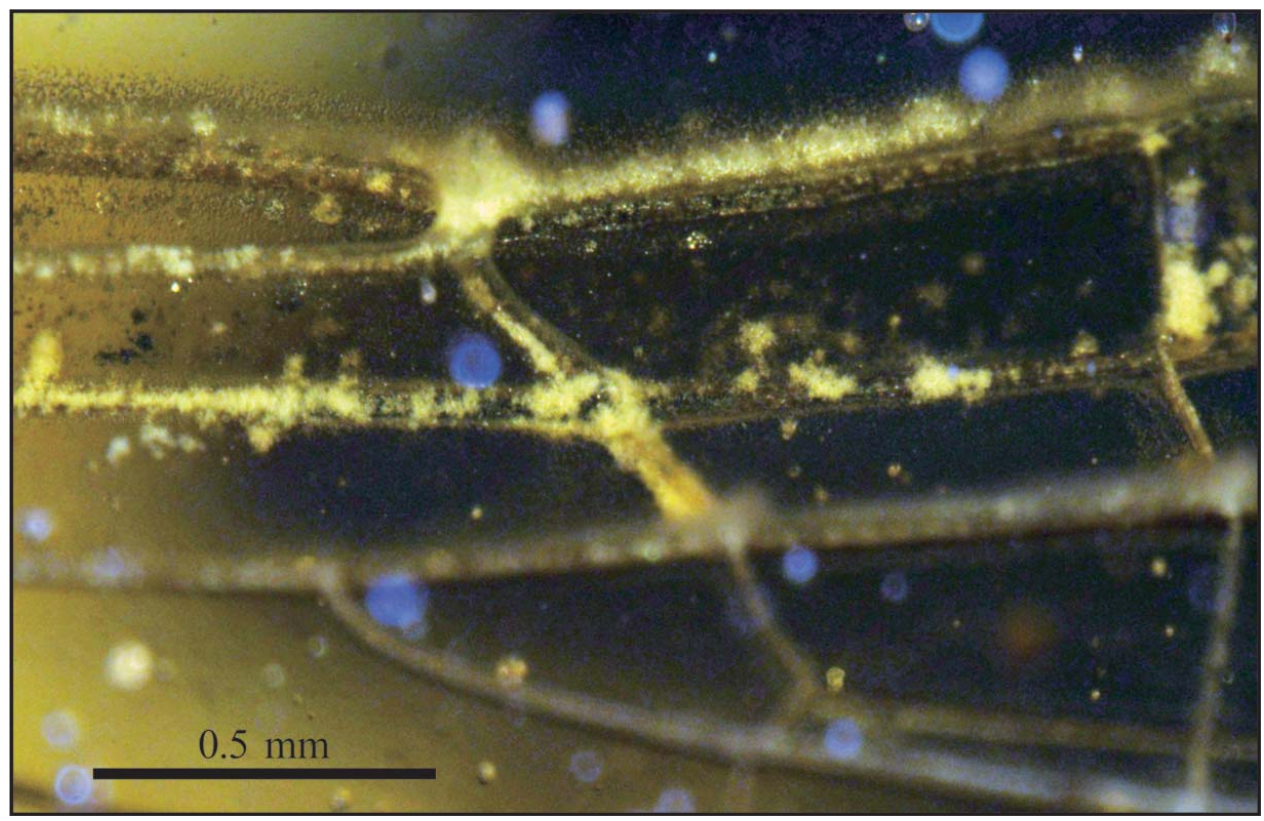

Figure 5. Mesosticta davidattenboroughi sp. nov., holotype, NIGP164541, photograph of right forewing nodus. 


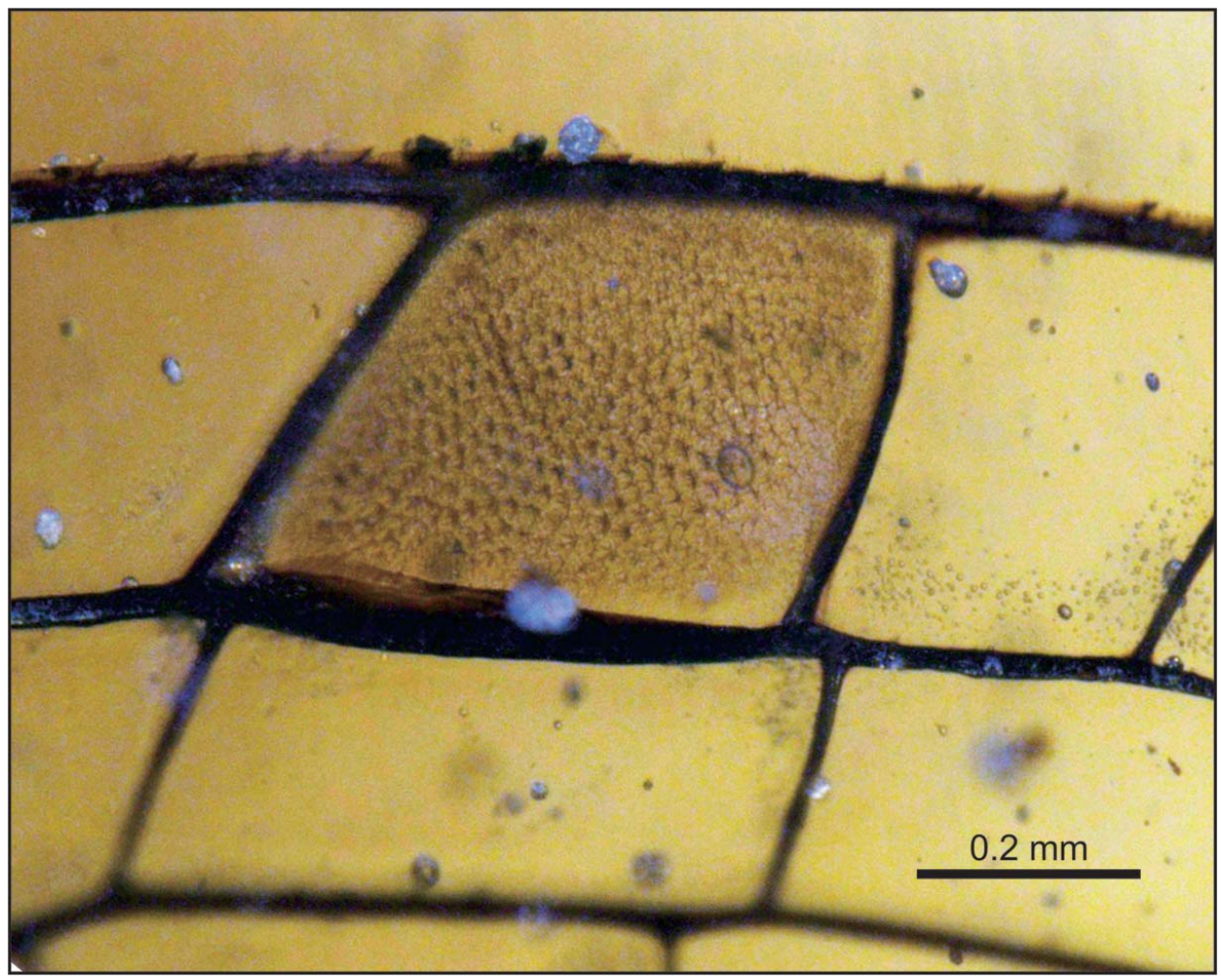

Figure 6. Mesosticta davidattenboroughi sp. nov., holotype, NIGP164541, photograph of right forewing pterostigma.

Description. Forewings complete (Figs 2, 3). Wing length $11.62 \mathrm{~mm}$, width at level of $\mathrm{N} 1.85 \mathrm{~mm}$; length from wing base to Arc $1.46 \mathrm{~mm}$, from Arc to $\mathrm{N} 1.85 \mathrm{~mm}$, from $\mathrm{N}$ to Pt $6.62 \mathrm{~mm}$, from Pt to wing apex $1.69 \mathrm{~mm}$. Primary antenodal crossveins preserved, Ax2 $1.09 \mathrm{~mm}$ distal of Ax1; no secondary antenodal crossveins present. Eight postnodal crossveins and eight postsubnodal crossveins present proximal to $\mathrm{Pt}$, somewhat aligned. Six postnodal crossveins and five postsubnodal crossveins present distal of Pt, non-aligned. Arc angular and aligned with Ax2. DC basally closed, free, elongate and quadrangular, $0.79 \mathrm{~mm}$ long and maximum $0.27 \mathrm{~mm}$ wide. Subdiscoidal cell free and elongate, $1.29 \mathrm{~mm}$ long and maximum $0.24 \mathrm{~mm}$ wide, crossed by one vein slightly basal of Arc. AA separated from $\mathrm{AP}$ at mid distance between $\mathrm{Ax} 1$ and $\mathrm{Ax} 2$, ending on distal angle of DC (Fig. 4). Nodal structures well preserved (Fig. 5), with Sn aligned with Cr. Midfork (base of RP3/4) slightly basal of N. IR2 aligned with Sn, one cell and $0.51 \mathrm{~mm}$ distal of midfork. RP2 three cells distal of Sn, lying $1.95 \mathrm{~mm}$ distally, nearer to $\mathrm{N}$ than to Pt. IR1 long, originating one cell distal of base of RP2 and five cells basal of Pt base. RP1 with a slight angle below Pt brace. Longitudinal veins RA, RP1, IR1, RP2 and IR2 strongly converging on wing apex. MA distally zigzagged and long, reaching posterior wing margin just below base of Pt-brace. MP curved, four cells long, ending on posterior wing margin $2.38 \mathrm{~mm}$ distal of distal angle of DC. Pt covering one cell (Fig. 6), $0.52 \mathrm{~mm}$ long and $0.44 \mathrm{~mm}$ wide, thickened and fused with greatly thickened pterostigmal part of RA as a U-shaped structure.

\section{Discussion}

Mesosticta davidattenboroughi has nearly all the characters of the genus Mesosticta Huang, Azar, Cai \& Nel, 2015, after Zheng et al. (2016a), listed here: (1) base of RP3/4 just basal of Sn; (2) base of RP2 three or four cells distal of Sn; (3) MA long but ending two cells distal of level of base of IR1; (4) MP three or four cells long; (5) $\mathrm{CuP}$ in basal position; (6) basal crossvein present closing subdiscoidal cell, seperate from CuP; (7) subdiscoidal cell posteriorly closed by AA and not by posterior wing margin; (8) RP1 with slight angle below pterostigmal brace; (9) IR1 three cells distal of base of RP2, nearer to Pt than to base of RP2; (10) postnodal and postsubnodal cossveins aligned slightly distal of $\mathrm{N}$ and basal of base of IR1; (11) longitudinal veins RA, RP1, IR1, RP2 and IR2 strongly converging on wing apex; and (12) Pt covering one cell, thickened and fused with greatly thickened pterostigmal part of RA as U-shaped structure. Mesosticta davidattenboroughi shares all the above characters except (3) and (9) due to the long IR1. In fact, MA reaches the posterior wing margin just below the pterostigmal brace in $M$. 


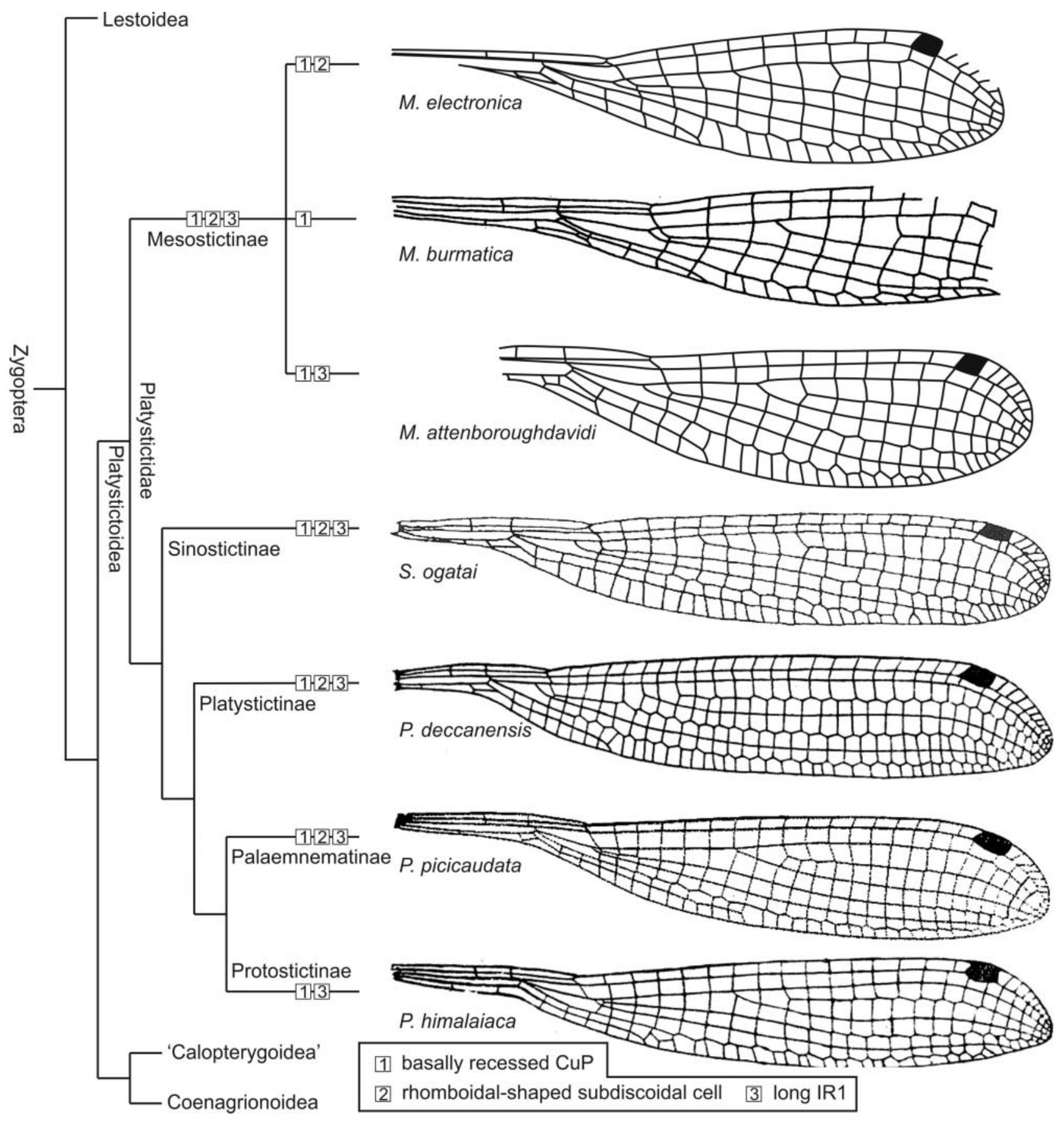

Figure 7. Hypothetical position of Mesosticta davidattenboroughi sp. nov. in phylogenetic tree of Zygoptera. All line drawings are based on forewings (phylogeny based on Dijkstra et al. 2014; line drawing of Sinosticta ogatai Matsuki \& Saito, 1996 after Wilson 1997; line drawing of Palaemnema picicaudata Kennedy, 1938 after Kennedy 1938; line drawings of Platysticta deccanensis Laidlaw, 1915 and Protosticta himalaiaca Laidlaw, 1917 after Fraser 1933).

davidattenboroughi and two previously described species of Mesosticta. M. davidattenboroughi has the base of IR1 shifted basally and only one cell distal of base of RP2, closer to the nodus than to the pterostigma, while the other species of Mesosticta have the base of IR1 three cells distal of the base of RP2 and nearer to the pterostigma. Due to the similarity with the other Mesosticta, we attribute $M$. davidattenboroughi to Mesosticta by revising the generic character (3) as 'MA long and reaching posterior wing margin just below pterostigmal brace' and removing 
character (9) to differentiate the species. Within Mesosticta (Fig. 7), M. davidattenboroughi has a crossvein across the basal part of the subdiscoidal cell, differing from M. burmatica which has a crossvein in the distal part of the subdiscoidal cell, and M. electronica which has a free, rhomboidal subdiscoidal cell. M. davidattenboroughi also has the arculus aligned with Ax2, as in M. burmatica but unlike M. electronica which has Ax2 slightly basal of the arculus.

The fossil genus Mesosticta has the diagnostic characters of the modern platystictid genera (Fig. 7), viz. a basally recessed 'CuP' (shared by all species), a very long IR1 (in M. davidattenboroughi), and a specialized subdiscoidal area mostly rhomboidal in shape (rhomboidal shape shared with $M$. electronica). The presence of these characters confirms the previous attribution of Mesosticta to Platystictidae. However, all these characters are not shared by one species as in most recent Platystictidae. Also, Mesosticta shares with the extant platystictid damselflies the following characters: vein RP1 with a very slight angle below the pterostigmal brace; postnodal and postsubnodal crossveins somewhat aligned; longitudinal veins RA, RP1, IR1, RP2 and IR2 strongly converging on wing apex; pterostigma one cell long, thickened and fused with greatly thickened pterostigmal part of RA to form a U-shaped structure.

The differences between the modern platystictid damselflies and Mesosticta (Fig. 7) are that the former have more postnodal and postsubnodal crossveins (over 15 compared to 10 or fewer in Mesosticta), a long MP (at least five cells long in Protostictinae to over half the wing length in Sinostictinae, compared with three or four cells long in Mesosticta - the shortening of the vein MP being a potential synapomorphy of the Mesostictinae), the base of RP2 being more cells distal of the subnodus (at least four cells compared to only three or four cells in Mesosticta) and the nodus lying very basally (23-30\% of the wing length compared to at least $35 \%$ in the latter). Due to the above differences, we establish a new subfamily Mesostictinae for the fossil platystictid damselflies from Burmese amber, representing the archaic platystictid damselflies.

\section{Acknowledgements}

This research was supported by the National Natural Science Foundation of China (grant numbers 41572010, 41622201, 41688103), Youth Innovation Promotion Association of the Chinese Academy of Sciences (grant number2011224), and the HKU Seed Funding Program for Basic Research (grant number 201210159058). We offer our sincere gratitude to the two anonymous reviewers for their very useful comments on an earlier version of the manuscript.

\section{References}

Bechly, G. 1996. Morphologische Untersuchungen am Flügelgeäder der rezenten Libellen und deren Stammgruppenvertreter (Insecta; Pterygota; Odonata), unter besonderer Berücksichtigung der Phylogenetischen Systematik und des Grundplanes der Odonata. Petalura, 2, 1-402.

Bechly, G. \& Poinar, G. Jr 2013. Burmaphlebia reifi gen. et sp. nov., the first anisozygopteran damsel-dragonfly (Odonata: Epiophlebioptera: Burmaphlebiidae fam. nov.) from Early Cretaceous Burmese amber. Historical Biology, 25, 233-237.

Bedjanič, M., Conniff, K., Dow, R. A., Stokvis, F. R., Verovnik, R. \& van Tol, J. 2016. Taxonomy and molecular phylogeny of the Platystictidae of Sri Lanka (Insecta: Odonata). Zootaxa, 4182, 1-80.

Cruickshank, R. D. \& Ko, K. 2003. Geology of an amber locality in the Hukawng Valley, northern Myanmar. Journal of Asian Earth Sciences, 21, 441-455.

Dijkstra, K.-D. B., Kalkman, V. J., Dow, R. A., Stokvis, F. R. \& van Tol, J. 2014. Redefining the damselfly families: a comprehensive molecular phylogeny of Zygoptera (Odonata). Systematic Entomology, 39, 68-96.

Dow, R. A. \& Orr, A. G. 2012. Telosticta, a new damselfly genus from Borneo and Palawan (Odonata: Zygoptera: Platystictidae). The Raffles Bulletin of Zoology, 60, 361-397.

Dow, R. A, Afendy, A. \& Rahman, H. 2016. Telosticta fugispinosa sp. nov. from Sabah (Odonata: Zygoptera: Platystictidae). Zootaxa, 4103, 390-395.

Fabricius, J. C. 1793. Entomologia systematica emendata et aucta, secundum classes, ordines, genera, species, adjectis synonymis, locis, observationibus, descriptionibus. C.G. Proft, Hafniae (= Copenhagen), 3, 1-487 and 1-349.

Fraser, F. C. 1931. Indian dragonflies. Part XXXVII. Journal of the Bombay Natural History Society, 35, 66-76.

Fraser, F. C. 1933. Odonata. Pp. i-xiii and 1-423 in J. Stephenson (ed.) The fauna of British India, including Ceylon and Burma, 1. Taylor \& Francis, London.

Fraser, F. C. 1957. A reclassification of the order Odonata, based on some new interpretations of the venation of the dragonfly wing. Handbook of the Royal Zoological Society of New South Wales, 12, 1-133.

Haber, W. \& Wagner, D. 2014. Platystictidae-shadowdamsels, forest damsels. Dragonflies and damselflies of Ecuador (Odonata). [updated at http://bdei2.cs.umb.edu/ whaber/ Odonata_of_Ecuador/index.html, accessed 15 July 2016].

Huang, D., Azar, D., Cai, C. \& Nel, A. 2015. New damselfly genera in the Cretaceous Burmese amber attributable to the Platystictidae and Platycnemididae Disparoneurinae (Odonata: Zygoptera). Cretaceous Research, 56, 237-243.

Jarzembowski, E. A., Martínez-Declòs, X., Bechly, G., Nel, A., Coram, R. \& Escuillié, F. 1998. The Mesozoic non calopterygoid Zygoptera: description of new genera and species from the lower Cretaceous of England and Brazil and their phylogenetic significance (Odonata, Zygoptera, Coenagrionoidea, Hemiphlebioidea, Lestoidea). Cretaceous Research, 19, 403-444.

Kania, I., Wang, B. \& Szwedo, J. 2015. Dicranoptycha Osten Sacken, 1860 (Diptera, Limoniidae) from the earliest Upper Cretaceous Burmese amber. Cretaceous Research, 52, 522530.

Kennedy, C. H. 1920. The phylogeny of the zygopterous dragonflies as based on the evidence of the penes. Ohio Journal of Science, 21, 19-29.

Kennedy, C. H. 1938. Palaemnema picicaudata, P. abbreviata and $P$. brucelli, new dragonflies from Ecuador, with notes 
on other Palaemnemas (Odonata: Platystictidae). Annals of the Entomological Society of America, 31, 249-266.

Laidlaw, F. F. 1915. Notes on Oriental dragonflies in the Indian Museum. No. 3. Indian species of the 'Legion' Protoneura. Records of the Indian Museum, 11, 387-391.

Laidlaw, F. F. 1917. A list of the dragonflies recorded from the Indian Empire with special reference to the collection of the Indian Museum. Part 2. The family Agrioninae. A. The sections Podolestes, Platycnemis, Platysticta and Protoneura. Records of the Indian Museum, 13, 321-348.

Matsuki, K. \& Saito, Y. 1996. A new species of Drepanosticta from Hong Kong (Platystictidae, Odonata). Nature and Insects, 31, 39-43.

Nel, A., Martinez-Delclòs, X., Paicheler, J. C. \& Henrotay, M. 1993. Les 'Anisozygoptera' fossiles. Phylogénie et classification (Odonata). Martinia Hors Série, 3, 1-311.

Phan, Q. T. \& Kompier, T. 2016. A study of the genus Protosticta Selys, 1855, with descriptions of four new species from Vietnam (Odonata: Platystictidae). Zootaxa, 4098, 529-544.

Poinar, G. Jr, Bechly, G. \& Buckley, R. 2010. First record of Odonata and a new subfamily of damselflies from Early Cretaceous Burmese amber. Palaeodiversity, 3, 15-22.

Riek, E. F. 1976. A new collection of insects from the Upper Triassic of South Africa. Annals of the Natal Museum, 22, 791-820.

Riek, E. F. \& Kukalová-Peck, J. 1984. A new interpretation of dragonfly wing venation based upon Early Carboniferous fossils from Argentina (Insecta: Odonatoidea) and basic character states in pterygote wings. Canadian Journal of Zoology, 62, 1150-1166.

Ross, A., Mellish, C., York, P. \& Crighton, B. 2010. Chapter 12. Burmese amber. Pp. 208-235 in D. Penney (ed.) Biodiversity of fossils in amber from the major world deposits. Siri Scientific Press, Manchester.

Sánchez-Herrera, M. \& Ware, J. L. 2012. Biogeography of dragonflies and damselflies: highly mobile predators. Pp. 291-306 in L. Stevens (ed.) Global advances in biogeography. Intech Publishers, Rijeka.

Schädel, M. \& Bechly, G. 2016. First record of Anisoptera (Insecta: Odonata) from mid-Cretaceous Burmese Amber. Zootaxa, 4103, 537-549.

Schorr, M. \& Paulson, D. 2015. World Odonata List. [updated at http://www.pugetsound.edu/, accessed 15 July 2016].

Selys-Longchamps, E. de 1854. Monographie des Calopterygines. Mémoires de la Société royale des Sciences de Liége, 9, $x i+291 \mathrm{pp}$.

Selys-Longchamps, E. de 1860. Synopsis des Agrionines. Dernire legion: Protoneura. Bulletin Academie royale Belgique Serie 2, 10, 431-462.
Selys-Longchamps, E. de 1885. Programme d'une révision des Agrionines. Annales de la Société entomologique de Belgique, 29, cxli-cxlvi.

Shi, G., Grimaldi, D. A., Harlow, G. E., Wang, J., Wang, J., Wang, M., Lei, W., Li, Q. \& Li, X. 2012. Age constraint on Burmese amber based on U-Pb dating of zircons. Cretaceous Research, 37, 155-163.

Suhling, F., Sahlén, G., Gorb, S., Kalkman, V. J., Dijkstra, K.-D. B. \& van Tol, J. 2015. Order Odonata. Pp. 893-932 in J. H. Thorp \& D. C. Rogers (eds) Ecology and general biology: Thorp and Covich's freshwater invertebrates. Academic Press, San Diego.

van Tol, J. 2005. Revision of the Platystictidae of the Philippines (Odonata), excluding the Drepanosticta halterata group, with descriptions of twenty-one new species. Zoologische Mededelingen, 79, 195-282.

van Tol, J. \& Müller, R. A. 2003. Forest damselflies of the Philippines, their evolution and present status, with the description of Drepanosticta moorei sp. nov. from Luzon (Zygoptera: Platystictidae). Odonatologica, 32, 39-45.

van Tol, J., Reijnen, B. T. \& Thomassen, H. A. 2009. Phylogeny and biogeography of the Platystictidae (Odonata). Pp. 370 in J. van Tol (ed.) Phylogeny and biogeography of the Platystictidae (Odonata). PhD thesis, Leiden University, Leiden.

Wang, B., Xia, F., Wappler, T., Simon, E., Zhang, H., Jarzembowski, E. A. \& Szwedo, J. 2015. Brood care in a 100million-year-old scale insect. eLife, 4, e05447.

Wilson, K. D. P. 1997. The Platystictidae of Hong Kong and Guangdong, with descriptions of a new genus and two new species (Zygoptera). Odonatologica, 26, 53-63.

Zheng, D., Zhang, Q., Chang, S.-C. \& Wang, B. 2016a. A new damselfly (Odonata: Zygoptera: Platystictidae) from midCretaceous Burmese amber. Cretaceous Research, 63, 142 147.

Zheng, D., Wang, B., Jarzembowski, E. A., Chang, S.-C. \& Nel, A. 2016b. The first fossil Perilestidae (Odonata: Zygoptera) from mid-Cretaceous Burmese amber. Cretaceous Research, 65, 199-205.

Zheng, D., Wang, B., Jarzembowski, E. A., Chang, S.-C. \& Nel, A. 2016c. Burmadysagrioninae, a new subfamily (Odonata: Zygoptera: Dysagrionidae) from mid-Cretaceous Burmese amber. Cretaceous Research, 67, 126-132.

Zheng, D., Zhang, Q., Jarzembowski, E. A., Zhou, Z., Chang, S.-C., Wang, B. \& Nel, A. 2016d. New damselflies (Odonata: Zygoptera: Hemiphlebiidae, Dysagrionidae) from midCretaceous Burmese amber. Alcheringa, 41, 12-21. 